Revista Mexicana de Economía y Finanzas Nueva Época

Volumen 14 Número 2, Abril-Junio 2019, pp. 189-202

DOI: https://doi.org/10.21919/remef.v14i2.309

\title{
Optimal Reciprocal Dumping in a Managed Trade Regime ${ }^{1}$ \\ Alberto Gallegos David ${ }^{2}$ \\ Universidad Anáhuac México, México \\ (Recepción: 20/junio/2018, aceptado: 8/octubre/2018)
}

\section{Abstract}

The purpose of this article is to examine the strategic relationship between trade policy in a managed protection regime and commercial exchange at prices below normal value. It presents a three-stage model of imperfect competition that incorporates the possibility for the government authority to influence the production decisions of companies through a credible threat, by means of a specific tariff. This methodology - in a context of segmented markets, Cournot conjectures, and the application of an optimal tariff-generates a mechanism of incentives (which are not sufficient from a social welfare perspective) for domestic and foreign companies to practice reciprocal dumping. A general conclusion is that a free trade policy would be counterproductive, since it would eliminate the incentives that domestic and foreign companies would have to carry out the commercial exchange that would diminish the loss of welfare associated with the existence of monopolies in both markets.

JEL Classification: F12

Keywords: Cournot competition, Managed trade, Reciprocal Dumping

\section{Dumping recíproco óptimo bajo un régimen de protección administrada}

\section{Resumen}

El propósito de este artículo es el de examinar la relación estratégica que existe entre la política comercial en un régimen de protección administrada y el intercambio comercial a precios por debajo del valor normal. Presento un modelo de competencia imperfecta en tres etapas que incorpora la posibilidad de que la autoridad gubernamental influya sobre las decisiones de producción de las empresas a través una amenaza creíble, mediante el uso de un arancel específico. Esta metodología, en un contexto de mercados segmentados, conjeturas à la Cournot y la aplicación de un arancel óptimo, genera como resultado un mecanismo de incentivos -que no son suficientes desde una perspectiva de bienestar social-, para que las empresas doméstica y extranjera realicen una práctica de dumping recíproco. Una conclusión general, es que una política de libre comercio sería contraproducente, pues ésta eliminaría los incentivos que las empresas doméstica y extranjera tendrían para realizar el intercambio comercial que disminuiría la pérdida de bienestar asociada a la existencia de monopolios en ambos mercados.

Clasificación JEL: F12

Palabras clave: Competencia Cournot, Comercio administrado, Dumping Recíproco.

\footnotetext{
${ }^{1}$ I would like to thank participants at the XXVII Coloquio Mexicano de Economía Matemática y Econometría, as well as two anonymous referees who helped improve earlier versions of this manuscript.

${ }^{2}$ Universidad Anáhuac México Campus Norte, Av. Universidad Anáhuac 46, Col. Lomas Anáhuac, Huixquilucan, Estado de México, C.P. 52786. Tel: 56270210 ext. 8161. Buzón electrónico: alberto.gallegos@anahuac.mx.
} 


\section{Introduction}

Without any doubt, the Uruguay Round (UR) has been one of the cornerstones in the relatively recent development and flourishing of international trade. Trade barriers that prevailed in the post-war era were lowered following the principles of the original General Agreement on Tariffs and Trade Agreement (GATT 47). However, new protectionist measures have recently been arising, threatening to offset the gains derived from the continuing liberalization of the international trade.

Antidumping and countervailing duties have been one of the most popular and active forms to "preventünfair trade practices among Members of the World Trade Organization (WTO), but its popularity is mainly due, inter alia, to the ambiguities of the legal procedure to find the causal link between the margin of dumping and the material injury observed and the lack of a much more formal methodology of proof of injury, which has led to several discreet interpretations. Nevertheless, in the last successful multilateral negotiation, Members of the WTO were agreed in making certain amendments and inclusions in order to implement the Antidumping Agreement as we know it nowadays ${ }^{3}$.

The last decade widespread use of the antidumping code among some emerging and advanced countries alike, has called the attention of several economists concerned with the effects of the antidumping duties on the international trade and the arise of just another form of the so called new protectionism. Miranda et. al. (1998), mentioned that the application of the antidumping code has become a back-door clause, specially used when closed economies have started liberalizing its trade policy towards a freer trade. Finger (1992), pointed out that the use of antidumping measures is just a customized way to apply custom-valuation procedures and then, a new form of protectionism. Boltuck (1987), justifies the application of antidumping duties in the unlikely event of finding predatory dumping and points out that the antidumping code is like an.${ }^{\mathrm{es}}$ cape valve"for those domestic firms that claim for protection at any cost.

There is a vast literature on the price-discrimination between national markets on the grounds of the unfair competitive aspects of the practice by itself, the motives to incur in this illegal practice of international trade, along with a number of variants about the effects of the price-discrimination in terms of the "softness. ${ }^{\circ} \mathrm{r} .{ }^{\text {aggressiveness. }}{ }^{\circ}$ the implicit price-competition between firms and also, a number of papers that distinguish global and domestic welfare effects of practicing dumping, even reciprocally or reversely between countries ${ }^{4}$.

In this paper, I analyze the optimal dumping that reflects the use of administered protection through the application of optimal trade taxes to identify welfare implications of the practice of reciprocal price-discrimination between national markets, fueled by the limited credibility that the government has, providing administered protection ${ }^{5}$.

Following Brander and Krugman (1983), Dixit (1988) and Regibeau and Gallegos (2004), in this paper the main insight can be analyzed with a model of two countries and two firms that face a monopoly distortion in autarky, and at the same time, that both firms have the perception of a market segmentation in the counterpart's market that makes each firm to have extraordinary revenues, if competition takes place at a lower price in the counterpart's market ${ }^{6}$.

\footnotetext{
${ }^{3}$ The Uruguay Round was launched in Punta del Este, Uruguay; on September of 1986, and ended in Marrakesh, Morocco; on April 1994.

${ }^{4}$ For a recent literature review on dumping, see Blonigen and Prusa (2015), and Nelson (2006). For a review on dumping investigations and dispute settlement issues, see Feinberg and Reynolds (2018).

${ }^{5}$ For a review on this argument see Brander and Krugman (1983), Dixit (1984), Brander and Spencer (1985), Regibeau and Gallegos (2006), and Gallegos (2017).

${ }^{6}$ This argument is crucial to build a case of bilateral trade where the practice of dumping takes place. Unlike Dixit (1988) and Lahiri (1990), this paper does not assume that to dump in a foreign market, a subsidy from the government to the domestic firm, must be necessary.
} 
In so doing, I propose a three-stage game: i) during the first stage, domestic and foreign firms take an entry-choice decision in its own market, ii) in the second stage, the domestic government chooses the degree of administered trade protection, and iii) during the third stage, domestic and foreign firms dump each other competing à la Cournot in the domestic and foreign markets.

In this model, the sequence of the game is crucial: it explores the strategic interaction between oligopolistic firms and governments in an international trade context. Brander and Spencer (1983), Spencer and Brander (1983) and Eaton and Grossman (1986), pointed out how the profit-shifting motive for intervention -correctly sequenced-, through the implementation of an optimal trade policy well before firms make their choice, can improve national welfare by influencing the strategic interaction between firms.

The mechanism linking the practice of reciprocal dumping and trade in this paper, is that trade provides home and foreign governments with a credible threat that motivates home and foreign firms to reciprocally dump in each other's market. The credibility of this limited commitment relies upon the fact that both home and foreign governments have a clear incentive to protect a firm with the aim to dump in a foreign market, expecting that the protected firm will be dumped in its national market. In this context, moving from autarky to free trade would be disadvantageous as it would remove the incentives national and foreign firms have to trading each other through the unfair practice of reciprocally dumping.

Unlike Oshiro (2013), where tariff competition and sufficiently low transport costs led to a free trade equilibrium, in this model, the optimal tariff depends on the price elasticity of the demand in the segmented market and the market share of the dumped exports in the national market. In this context, a policy of free trade would be counterproductive because it would eliminate the private incentives both firms have to reciprocally dump.

Instead of assuming that national and foreign firms produce a homogeneous good, Friberg and Ganslandt (2008) designed a model of reciprocal dumping with product differentiation that extends the analysis of intra-industry trade with differentiated products in a price-competition framework. Friberg and Ganslandt (2008), pointed out that trade can reduce welfare when moving from autarky to free trade in a Cournot type model, for any degree of product differentiation. This result is aligned with that of Brander and Krugman (1983), where transport costs of the iceberg-type might be so high, that more than compensate gains coming from the consumer and producer surpluses.

In Section I, I set up the model and show general results for an implicit inverse demand function. In Section II, I use a linear inverse demand function to show specific results through the three-stage game of this model where the optimal trade tax is obtained. In Section III, I extend the model to allow for a non-cooperative interaction between home and foreign governments in setting up the optimal trade tax. The paper ends with some concluding remarks.

\section{The Model}

Consider a model with two open economies, home and foreign, and two identical firms. Both firms have symmetric cost structures and produce a homogeneous good. In autarky both firms act as a monopoly. Both countries trade each other, only if there is a perception of a segmented market demand in the counterpart's market, and if there is a transport cost not too high.

The model is designed as a three-stage game. During the first stage, the domestic firm chooses to enter the market at a cost F, implicitly determining its productive capacity ${ }^{7}$. In

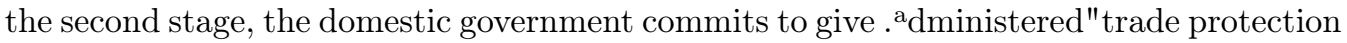
in the form of a specific trade tax $t$, preventing the domestic firm to be "predated"from

\footnotetext{
${ }^{7}$ If the fixed cost is set too high, unless the government commits to administer protection in the second stage, firms do not invest. Firms in specific sectors like steel, cement, cupper, oil, etc., are of this type.
} 
the foreign country. At the third stage, the domestic and foreign symmetric firms compete à la Cournot in the domestic and foreign markets.

In this context, both home and foreign countries are small open economies that perceive that there is a market segmentation in the counterpart's market and face not prohibitive transport costs. As is usual, I will solve for the subgame perfect equilibrium by backward induction.

A natural generalization of this setting is to allow for conjectural variations, even in the case where marginal costs are set to be zero with the aim to eliminate any "strategic trade. ${ }^{e f} f e c t s$, and to further explore using a specific inverse parametric demand function.

\subsection{Third stage: firms compete à la Cournot}

During the third stage of the game, each firm believes that the other will hold its output fixed while the output level of that firm changes ${ }^{8}$. At this point, each firm has already considered that both markets are segmented. Profit functions for each of the firms take the following form:

$$
\pi_{1}\left(x_{1}, x_{2} ; t_{1}\right)=P(Q) x_{1}+P(Z) y_{1}-c x_{1}-\left(c+\tau+t_{2}\right) y_{1}-F_{1}
$$

For the domestic firm, and:

$$
\pi_{2}\left(y_{1}, y_{2} ; t_{2}\right)=P(Q) y_{2}+P(Z) x_{2}-c y_{2}-\left(c+\tau+t_{1}\right) x_{2}-F_{2}
$$

For the foreign firm $^{9}$.

Where $Q=x_{1}+x_{2}$, represents the domestic market demand, whereas $Z=y_{1}+y_{2}$, represents the foreign country's market demand, so that $P(Q)$ and $P(Z)$ are the prices for the domestic and the foreign markets, respectively, where the Cournot competition takes place.

Likewise, $\mathrm{F}$ stands for the fixed cost of entry, and $t_{1}$ is the specific trade tax "administered" by the domestic government, while $t_{2}$ is the specific trade tax . ${ }^{\text {administered"by }}$ the foreign government. Finally, I consider a constant marginal cost of production c for the domestic and foreign production levels and $\tau$ to export between countries, considering symmetric cost structures between countries.

Naturally, for the domestic market, reaction functions are obtained directly from $\frac{\partial \pi_{1}}{\partial x_{1}}=$ $\pi_{x_{1}}=0=\pi_{x_{2}}=\frac{\partial \pi_{2}}{\partial x_{2}}$. The foreign market reaction functions are similarly obtained from: $\frac{\partial \pi_{1}}{\partial y_{1}}=\pi_{y_{1}}=0=\pi_{y_{2}}=\frac{\partial \pi_{2}}{\partial y_{2}}$. Therefore, for the domestic market:

$$
\begin{gathered}
\pi_{x_{1}}=P(Q)+P^{\prime}(Q) x_{1}-c=0 \\
\pi_{x_{2}}=P(Q)+P^{\prime}(Q) x_{2}-\left(c+\tau+t_{1}\right)=0
\end{gathered}
$$

With second order conditions $\frac{\partial}{\partial x_{i}}\left[\frac{\partial \pi_{i}}{\partial x_{i}}\right]=\pi_{x_{i} x_{i}}<0$, for any $i=1,2$, and $\frac{\partial}{\partial x_{i}}\left[\frac{\partial \pi_{i}}{\partial x_{j}}\right]=$ $\pi_{x_{i} x_{j}}<0$, for any $i \neq j$, so that I have for the domestic market:

$$
\begin{aligned}
& \pi_{x_{1} x_{1}}=2 P^{\prime}(Q)+x_{1} P^{\prime \prime}(Q)<0 \\
& \pi_{x_{2} x_{2}}=2 P^{\prime}(Q)+x_{2} P^{\prime \prime}(Q)<0
\end{aligned}
$$

At this point, the question would be about the effect of the trade tax $t_{1}$ on the production levels realized for the domestic market. Totally differentiating eqs. (3) and (4) to get the answers for the following expressions: $\frac{d x_{1}}{d t_{1}}$ and $\frac{d x_{2}}{d t_{1}}$, I obtain:

$$
\begin{aligned}
& \pi_{x_{1} x_{1}} d x_{1}+\pi_{x_{1} x_{2}} d x_{2}+\pi_{x_{1} t_{1}} d t_{1}=0 \\
& \pi_{x_{2} x_{1}} d x_{1}+\pi_{x_{2} x_{2}} d x_{2}+\pi_{x_{2} t_{1}} d t_{1}=0
\end{aligned}
$$

\footnotetext{
${ }^{8}$ This means that $\frac{d q_{i}}{d q_{j}}=0$ for any $i \neq j$
}

${ }^{9}$ The foreign firm exports to the domestic country which has an import tariff in place. 
Since $\pi_{x_{1} t_{1}}=0$ and $\pi_{x_{2} t_{1}}=-1$, the equation system can be solved simultaneously to obtain:

$$
\begin{aligned}
& \frac{d x_{1}}{d t_{1}}=-\frac{\pi_{x_{1} x_{2}}}{\Delta}>0 \\
& \frac{d x_{2}}{d t_{1}}=\frac{\pi_{x_{1} x_{1}}}{\Delta}<0
\end{aligned}
$$

Where $\Delta=\pi_{x_{1} x_{1}} \pi_{x_{2} x_{2}}-\pi_{x_{2} x_{1}} \pi_{x_{1} x_{2}}>0^{10}$.

Provided the Routh-Hurwitz condition for reaction function stability takes place, eqs. (9) and (10) clearly show that an increase in the trade tax $t_{1}$, leads to a domestic output increase, while decreasing simultaneously the foreign output's share in the domestic market.

The analysis in the foreign country is quite similar. I will take the second subset of reaction functions. In the foreign market these are: $\frac{\partial \pi_{1}}{\partial y_{1}}=\pi_{y_{1}}=0=\pi_{y_{2}}=\frac{\partial \pi_{2}}{\partial y_{2}}$. Then I obtain:

$$
\begin{gathered}
\pi_{y_{1}}=P(Z)+P^{\prime}(Z) y_{1}-\left(c+\tau+t_{2}\right)=0 \\
\pi_{y_{2}}=P(Z)+P^{\prime}(Z) y_{2}-c=0
\end{gathered}
$$

With second order conditions $\frac{\partial}{\partial y_{i}}\left[\frac{\partial \pi_{i}}{\partial y_{i}}\right]=\pi_{y_{i} y_{i}}<0$, for any $i=1,2$, and $\frac{\partial}{\partial y_{i}}\left[\frac{\partial \pi_{i}}{\partial y_{j}}\right]=$ $\pi_{y_{i} y_{j}}<0$, for any $i \neq j$, i.e., for the foreign market:

$$
\begin{aligned}
& \pi_{y_{1} y_{1}}=2 P^{\prime}(Z)+y_{1} P^{\prime \prime}(Z)<0 \\
& \pi_{y_{2} y_{2}}=2 P^{\prime}(Z)+y_{2} P^{\prime \prime}(Z)<0
\end{aligned}
$$

Totally differentiating eqs. (11) and (12) to obtain the effects of $t_{2}$ on the production levels $y_{2}$ and $y_{1}$, I obtain symmetric results as those shown for the domestic market from the following equation system for the foreign country:

$$
\begin{aligned}
& \pi_{y_{1} y_{1}} d y_{1}+\pi_{y_{1} y_{2}} d y_{2}+\pi_{y_{1} t_{2}} d t_{2}=0 \\
& \pi_{y_{2} y_{1}} d y_{1}+\pi_{y_{2} y_{2}} d y_{2}+\pi_{y_{2} t_{2}} d t_{2}=0
\end{aligned}
$$

Since $\pi_{y_{1} t_{2}}=-1$ and $\pi_{y_{2} t_{2}}=0$, this equation system can be solved simultaneously to obtain:

$$
\begin{gathered}
\frac{d y_{1}}{d t_{2}}=\frac{\pi_{y_{2} y_{2}}}{\Delta}<0 \\
\frac{d y_{2}}{d t_{2}}=-\frac{\pi_{y_{2} y_{1}}}{\Delta}>0
\end{gathered}
$$

Where $\Delta=\pi_{y_{1} y_{1}} \pi_{y_{2} y_{2}}-\pi_{y_{2} y_{1}} \pi_{y_{1} y_{2}}>0$.

As I expected, the effect of the trade tax on the domestic exports' market share in the foreign market is negative, whereas the effect of the trade tax on the foreign production market share is positive. In both markets, the application of trade taxes, shifts to the left the counterpart's reaction function, reducing its counterpart's market share.

\footnotetext{
${ }^{10}$ Worth noting is that çross effects. ${ }^{a}$ re weaker than.${ }^{\circ}$ wn effects. ${ }^{\circ}$ n the reduction of the marginal revenue, i.e., $\pi_{x_{i} x_{i}}<\pi_{x_{i} x_{j}}$ for any $i \neq j$.
} 
Proposition 1: An increase in the trade tax committed by the domestic government:

a) Increases the domestic price of the good,

b) Increases the domestic market share,

c) Increases domestic profits, and

d) Reduces foreign profits.

Proof:
a) $\frac{\mathrm{dP}(Q)}{\mathrm{dt}_{1}}=\frac{\mathrm{P}^{\prime}(Q)}{\Delta}\left[\pi_{x_{1} x_{1}}-\pi_{x_{1} x_{2}}\right]>0$
b) $\frac{d\left(\frac{x_{1}}{Q}\right)}{\mathrm{dt}_{1}}=-\frac{\left(x_{2} \frac{\pi_{x_{1} x_{2}}}{\Delta}+x_{1} \frac{\pi_{x_{1} x_{1}}}{\Delta}\right)}{Q^{2}}>0$
c) $\frac{d \pi_{1}}{\mathrm{dt}_{1}}=x_{1} P^{\prime}(Q) \frac{\pi_{x_{1} x_{1}}}{\Delta}>0$
d) $\frac{d \pi_{2}}{\mathrm{dt}_{1}}=-\mathrm{x}_{2}<0$

\subsection{Second stage: the domestic government determines the optimal trade $\operatorname{tax} t_{1}$ :}

Under freely managed trade and with the aim to determine the optimal trade tax for the domestic economy, I proceed to examine the consumer and producer surpluses and trade revenues. These three elements allow me to have an expression for the domestic welfare function:

$$
W_{1}(\cdot)=\int_{0}^{Q} P(Q) d Q-P(Q) Q+\pi_{1}(\cdot)+t_{1} x_{2}
$$

First, let us obtain the sign of the optimal trade tax by obtaining $\frac{d W\left(t_{1}\right)}{d t_{1}}=0$. Therefore, on the consumer surplus the effect of the trade tax is as anticipated:

$$
\frac{d W_{1}(\cdot)}{d t_{1}}=-\mathrm{QP}^{\prime}(Q)\left(\frac{\pi_{x_{1} x_{1}}-\pi_{x_{1} x_{1}}}{\Delta}<0\right.
$$

Provided:

$$
\begin{gathered}
\frac{d x_{1}}{d t_{1}}=-\frac{\pi_{x_{1} x_{2}}}{\Delta}>0 \\
\frac{d x_{2}}{d t_{1}}=\frac{\pi_{x_{1} x_{1}}}{\Delta}<0
\end{gathered}
$$

On the producer surplus, the general expression is:

$$
\frac{d \pi_{1}}{d t_{1}}=\frac{\partial \pi_{1}}{\partial x_{1}} \frac{d x_{1}}{d t_{1}}+\frac{\partial \pi_{1}}{\partial x_{2}} \frac{d x_{2}}{d t_{1}}+\frac{\partial \pi_{1}}{\partial y_{1}} \frac{d y_{1}}{d t_{1}}+\frac{\partial \pi_{1}}{\partial y_{2}} \frac{d y_{2}}{d t_{1}}+\frac{\partial \pi_{1}}{\partial t_{1}} \frac{d t_{1}}{d t_{1}}
$$

From the first order conditions for the domestic firm, I know that: $\frac{\partial \pi_{1}}{\partial x_{1}}=0=\frac{\partial \pi_{1}}{\partial y_{1}}$. On the other hand, from eq. (1) I know that $\frac{\partial \pi_{1}}{\partial t_{1}}=0$. As for the remaining of the first order conditions for the domestic firm, although mixed between firms and countries, choices on $y_{2}$-taken by the foreign firm-, and on $x_{1}$-taken by the domestic firm-, can be thought of separately for firms 1 and 2 , respectively ${ }^{11}$. Finally, for the producer surplus the effect of the trade tax is unambiguously positive, as it was expected:

$$
\frac{d \pi_{1}}{d t_{1}}=x_{1} \mathrm{P}^{\prime}(Q) \frac{\pi_{x_{1} x_{1}}}{\Delta}>0
$$

Regarding the tariff revenue, the following expression reflects the negative effect the specific trade tax has on $x_{2}$, but considering that the specific trade tax is not prohibitive, this effect should be non-negative in a context where the trade tax plays the role of a countervailing duty ${ }^{12}$.

\footnotetext{
${ }^{11}$ Note that for this reason $\frac{\partial \pi_{1}}{\partial y_{2}}=0$.

${ }^{12}$ Dixit (1988), pointed out that due to the existence of market imperfections, cases of perfect competition and monopoly are pure benchmark theoretical cases, so that the application of a countervailing duty must be seen as a second-best trade policy.
} 


$$
\frac{d\left(t_{1} x_{2}\right)}{d t_{1}}=t_{1} \frac{\pi_{x_{1} x_{1}}}{\Delta}+x_{2} \geq 0
$$

Naturally, there is a negative effect coming from the consumer surplus, but as long as the trade tax is not prohibitive, that effect can be more than compensated by the effect of the trade tax on the producer surplus and the tariff revenues, plus the gain in the consumer surplus as a result of the practice of reciprocal dumping, so that the optimal trade tax would be no negative:

$$
t_{1}^{o p t}=Q P^{\prime}(Q)\left[1-\frac{\pi_{x_{1} x_{1}}}{\pi_{x_{1} x_{2}}}\right]-x_{1} P^{\prime}(Q)-x_{2} \frac{\Delta}{\pi_{x_{1} x_{1}}} \geq 0
$$

Accordingly, the optimal $t_{1}$ would be a function of the price elasticity of the demand in the domestic country, and the market share of the foreign exports in the domestic country $^{13}$, i.e., $t_{1}^{\text {opt }}=f(\alpha, \eta)(+)(+) \geq 0$. Where: $\alpha=\frac{x_{2}}{x_{1}+x_{2}}$ represents the market share of the foreign output in the domestic market demand, and $\eta=\frac{d Q}{d P} \frac{P}{Q}$, the price elasticity of the demand in the domestic country. The result shown in eq. (24) lead us to the following proposition:

Proposition 2: Even though the domestic government has a limited commitment, it has an incentive to independently provide a trade tax to the domestic firm because dumping is better than autarky for producers and consumers.

At this stage of the game, even though the government has a limited commitment, the sequence of the game -with the trade tax offered before the Cournot competition takes place-, influences firms' behavior, so that the non-cooperative equilibrium of the domestic government favors the domestic firm.

The intuition behind this result is as if the trade tax applied by the domestic government in stage two, with the aim to protect the domestic firm, played the role of a crossed subsidy on exports of the foreign firm. In this context, there is a profit-shifting motive for intervention ${ }^{14}$.

\subsubsection{A specific demand function: a general linear demand function}

Following Brander and Krugman (1983), if I define $\alpha=\frac{x_{2}}{Z}$ as representing the market share of the foreign output in the domestic market demand, and $\eta=\frac{d Q}{d P} \frac{P}{Q}=\frac{P(Q)}{P(Q) Q}$, as the price elasticity of the demand in the domestic country, I use the inverse linear demand function that exhibits standard features to obtain explicit solutions on $P, \eta$, and the domestic trade tax $t_{1}$. Be the inverse linear demand function the following:

$$
P(Q)=1-\left(x_{1}-x_{2}\right)
$$

From the first order conditions for the domestic economy, i.e., equations (3) and (4), and further defining $\alpha=\frac{x_{2}}{x_{1}+x_{2}}$, this implies that $1-\alpha=\frac{x_{1}}{x_{1}+x_{2}}$, and $\eta=\frac{d Q}{d P} \frac{P}{Q}=$ $\frac{1-\left(x_{1}+x_{2}\right)}{x_{1}+x_{2}}$, I obtain from eqs. (3) and $(4)^{15}$ :

$$
\begin{gathered}
P=\frac{\eta c}{\eta+(1-\alpha)} \\
P=\frac{\eta\left(c+\tau+t_{1}\right)}{\eta+\alpha}
\end{gathered}
$$

By solving simultaneously eqs. (26) and (27), I obtain solutions for the domestic price $\mathrm{P}$ and the implicit market share of the foreign exports in the domestic market:

\footnotetext{
${ }^{13}$ Although it is clear that $\frac{d y_{1}}{d t_{2}}<0$, the direct effect of the trade tax on at the prohibitive level will be zero

${ }^{14}$ Unlike Brander and Spencer (1983), in this case, both reaction functions shift, so that the StackelbergNash-equilibrium -when no trade tax is explicitly applied for the domestic country-, cannot be replicated.

${ }^{15}$ Notice that if by definition $\frac{x_{1}+x_{2}}{Q}=1$, then $\frac{x_{1}}{Q}=1-\frac{x_{2}}{Q}=1-\alpha$.
} 


$$
\begin{gathered}
\alpha^{*}=\frac{c+(1+\eta)\left(\tau+t_{1}\right)}{2 c+\tau+t_{1}} \\
P^{*}=\frac{\eta\left(2 c+\tau+t_{1}\right)}{2 \eta+1}
\end{gathered}
$$

From eq. (28) the specific trade tax can be seen as a function of the transport cost the price elasticity of demand in the counterpart's market $\eta^{16}$.

$$
t_{1}=\frac{\tau\left(1+\eta-\alpha^{*}\right)+c\left(1-2 \alpha^{*}\right)}{\left(\alpha^{*}-1-\eta\right)}
$$

At this point, I naturally ask for the effects of the trade tax on the market share of the foreign country's exports in the domestic country, and the determination of the domestic price, i.e., in looking for answers for $\frac{d \alpha^{*}}{d t_{1}}$ and $\frac{d P^{*}}{d t_{1}}$, I obtain:

$$
\begin{gathered}
\frac{d \alpha^{*}}{d t_{1}}=\frac{c(1+2 \eta)}{\left(2 c+\tau+t_{1}\right)^{2}}>0 \Leftrightarrow \eta>-\frac{1}{2} \\
\frac{d P^{*}}{d t_{1}}=\frac{\eta}{2 \eta+1}>0 \Leftrightarrow \eta>-\frac{1}{2}
\end{gathered}
$$

The intuition behind eq. (30) is that once the domestic firm takes the çommitment. ${ }^{\circ} \mathrm{f}$ its own government to provide administered protection as given, the foreign firm acknowledges that the domestic firm will start exporting at a lower price than that prevailing in its own market before trade takes place $^{17}$. At this point, the foreign firm that also has a

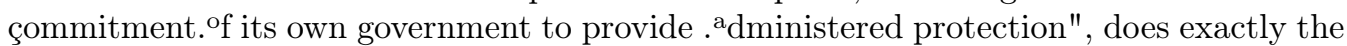
same as its counterpart: increasing the amount of exports to the domestic country, therefore, increasing its external market share. Answers to both questions are also expected in the absence of free trade ${ }^{18}$.

Worth noting is that equations (28) and (29) show a relationship between $\mathrm{P}$ and $\alpha$ : $\mathrm{P}$ must be clearly higher than $c+\tau$, for trade to take place. This means that for any positive $\alpha$, for $\mathrm{P}$ to be positive, I need:

$$
\eta>\frac{c+\tau}{\tau-t_{1}}
$$

In other words, the price elasticity of the domestic demand should be higher than $\frac{c+\tau}{\tau-t_{1}}$, as long as $t_{1}<\tau$, in order to have an interior solution for the price elasticity of the domestic market demand.

To determine the explicit solution for the optimal trade tax, I will follow the same methodology as before, i.e., totally differentiating the social welfare function in eq. (19). In doing so, I obtain the expressions for the consumer and producer surpluses, and the tariff revenue to analyze the welfare function of the domestic economy and finally obtain the optimal trade tax:

$$
t_{1}^{o p t}=\frac{1-\tau-c}{3}
$$

When I substitute the optimal trade tax already obtained to have interior solutions for $x_{1}$ and $x_{2}$, I obtain a relationship between the marginal cost $c$ and the transport cost $\tau:$

$$
2 c-2<\tau<\frac{1-c}{4}
$$

\footnotetext{
${ }^{16}$ Worth noting is that $\frac{d t_{1}}{d \tau}<0$ while $\frac{d t_{1}}{d \eta}=\frac{c\left(1-2 \alpha^{*}\right)}{\left(\alpha^{*}-1-\eta\right)^{2}}>0 \Leftrightarrow \alpha^{*}<\frac{1}{2}$ and $\rangle>-\frac{1}{2}$.

${ }^{17}$ Both $\frac{d \alpha^{*}}{d t_{1}}$ and $\frac{d P^{*}}{d t_{1}}$ do depend on $\eta>-\frac{1}{2}$. This means that the price elasticity of the domestic demand must reflect sufficient sensibility in order to have these results, in line with the domestic and foreign firms' perceptions about segmented markets, as already pointed out.

${ }^{18}$ The domestic country is imposing a trade tax, leaving aside the "free"trade regime. That is why the foreign exports' share reacts"positively to an increase in the domestic trade tax. Therefore, applying a trade tax does not reduce domestic welfare.
} 
Clearly, eq. (37) leads to the following relevant intervals for these parameters: $c \in(0,1)$ and $\tau \in\left(0, \frac{1}{4}\right)$.

Considering that in autarky conditions the domestic firm acts as a monopoly, the domestic firm has the following profit function:

$$
\pi^{A}=P(Q) x^{A}-c x^{A}
$$

Where $P(Q)$ is assumed to be the linear inverse demand function as before, i.e., $P(Q)=1-x^{A}$, with crepresenting as before, the marginal cost of production. In this case, the domestic firm acts as a monopolist with the following quantity choice $\frac{\partial \pi^{A}}{\partial x^{A}}=0$ :

$$
\begin{gathered}
x^{A}=\frac{1-c}{2} \Rightarrow \\
P(Q)=\frac{1+c}{2} \Rightarrow \\
\pi^{A}=\frac{(1-c)^{2}}{4}
\end{gathered}
$$

In this context, the implicit optimal dumping results from comparing the monopoly price determined by the domestic firm when the domestic country is in autarky $P^{A}$, with the price with dumping considering the optimal trade tax $P^{D}$. Accordingly, the inequality chain from the monopoly price to the marginal cost of production is the following:

$$
P^{A}=\frac{1+c}{2}>P^{D}=\frac{4+2 \tau+5 c}{9}>c+\tau>c
$$

For its realization, the price in the dumping scenario must not be lower than the marginal plus the transport costs, condition that is guaranteed if as it has already been mentioned: $c \in(0,1)$ and $\tau \in\left(0, \frac{1}{4}\right)^{19}$.

\subsection{First stage: entry choice}

At this stage of the game, the choice to enter the market for the domestic firm will reflect the possibility to obtain positive net benefits from having administered protection in a context of reciprocal dumping, compared to a situation of autarky that may cover or not, the fixed cost of entry $F_{1}$. In other words, the domestic firm will entry if:

$$
\pi_{1}\left(t_{1}^{\text {opt }}\right)-\pi_{1}\left(t_{1}=0\right)=F_{1}
$$

However, this means that the private incentive to enter the market may not be sufficient from the social welfare point of view. To analyze this, I examine through the private domestic welfare.

Let us define $B_{1}=\pi_{1}\left(t_{1}^{\text {opt }}\right)-\pi_{1}\left(t_{1}=0\right)$ as the domestic firm's incentive to dump in the foreign country, once substituting $t_{1}^{\text {opt }}$ using the general linear inverse demand function, I obtain the following expression for the domestic private welfare:

$$
B_{1}=\pi_{1}\left(t_{1}^{\text {opt }}\right)-\pi_{1}\left(t_{1}=0\right)
$$

In the absence of managed trade protection, the autarky equilibrium for the domestic firm implies that the domestic firm will have the following profit ${ }^{20}$ :

$$
\pi_{1}^{M}\left(t_{1}=0\right)=\frac{(1-c)^{2}}{4}
$$

And if both countries are reciprocally dumping at each other's market I obtain:

\footnotetext{
${ }^{19}$ Notice that according to the graph, adding the gain achieved on the consumer surplus to the domestic firm's markup, might be insufficient to compensate the cost of importing homogeneous product from abroad at $c+\tau$, instead of $c$, when the monopoly in place is clearly in autarky for comparison matters.

${ }^{20}$ Worth noting is that if countries are set to have a policy of free trade, there are no incentives for the firms to dump in the counterpart's market.
} 


$$
\pi_{1}\left(t_{1}^{o p t}, t_{2}^{o p t}\right)=\left(\frac{4+2 \tau-4 c_{x}}{9}\right)^{2}+\left(\frac{1-4 \tau-c_{y}}{9}\right)^{2}
$$

To finally get an explicit expression for the domestic private welfare in eq. (42):

$$
B_{1}=\left(\frac{4+2 \tau-4 c_{x}}{9}\right)^{2}+\left(\frac{1-4 \tau-c_{y}}{9}\right)^{2}-\frac{\left(1-c_{x}\right)^{2}}{4} \geq F_{1}
$$

If I additionally assume that both firms have symmetric cost structures with $c_{x}=c=$ $c_{y}$, where $c, \tau \gg 0$, and $c \in(0,1)$ with $\tau \in\left(0, \frac{1}{4}\right)$, the domestic private welfare is positive $B_{1} \geq 0$ and an increasing function in the transport $\tau$ and the marginal $c \operatorname{costs}^{21}$.

However, from the private welfare point of view and for entry costs $F_{1}$ relatively high, there might be not enough private incentives to enter the market and to dump in the counterpart's market.

\section{Two governments: optimal specific trade taxes}

In this section, actions and best responses of both domestic and foreign countries are considered in looking for the subgame perfect equilibrium at each of the stages of the game as in the analysis of the previous subsection, with just one country determining its optimal trade tax. In so doing, it is worth mentioning that the foreign firm has a symmetric cost structure and faces virtually the same incentives to dump in the domestic country. In this context, assuming that the inverse demand functions are linear in each country, the full set of reaction functions during the quantity-choice third stage game is the following:

For the domestic and foreign markets:

$$
\begin{aligned}
& \frac{\partial \pi_{1}}{\partial x_{1}}=\pi_{x_{1}}=0=\pi_{x_{2}}=\frac{\partial \pi_{2}}{\partial x_{2}} \\
& \frac{\partial \pi_{1}}{\partial y_{1}}=\pi_{y_{1}}=0=\pi_{y_{2}}=\frac{\partial \pi_{2}}{\partial y_{2}}
\end{aligned}
$$

Solving both systems allows us to see symmetric responses in terms of the quantity choice for both domestic and foreign countries:

In the domestic market:

$$
\begin{gathered}
x_{1}=\frac{1+\tau+t_{1}-c_{x}}{3} \\
x_{2}=\frac{1-2 \tau-2 t_{1}-c_{x}}{3}
\end{gathered}
$$

And in the foreign market:

$$
\begin{gathered}
y_{1}=\frac{1-2 \tau-2 t_{2}-c_{y}}{3} \\
y_{2}=\frac{1+\tau+t_{2}-c_{y}}{3}
\end{gathered}
$$

The resulting market demands and price in the domestic market:

$$
\begin{gathered}
Q=\frac{2-\tau-t_{1}-2 c_{x}}{3} \\
P(Q)=\frac{1+\tau+t_{1}+2 c_{x}}{3}
\end{gathered}
$$

And in the foreign market:

$$
\begin{gathered}
Z=\frac{2-\tau-t_{2}-2 c_{y}}{3} \\
P(Z)=\frac{1+\tau+t_{2}+2 c_{y}}{3}
\end{gathered}
$$

${ }^{21}$ Worth noting is that: $\frac{\partial\left(\frac{\partial B_{1}}{\partial c}\right)}{\partial \tau}>0$ and $\frac{\partial\left(\frac{\partial B_{1}}{\partial c}\right)}{\partial c}>0 \Leftrightarrow \frac{c-1}{5}<\tau<\frac{13-13 c}{16}$ 
Along with the profit functions in the domestic and foreign markets:

$$
\begin{aligned}
& \pi_{1}=\frac{\left(1+\tau+t_{1}-c_{x}\right)^{2}}{9}+\frac{\left(1-2 \tau-2 t_{2}-c_{y}\right)^{2}}{9}-F_{1} \\
& \pi_{2}=\frac{\left(1+\tau+t_{2}-c_{y}\right)^{2}}{9}+\frac{\left(1-2 \tau-2 t_{1}-c_{x}\right)^{2}}{9}-F_{2}
\end{aligned}
$$

As is usual, by backward induction I solve for the subgame perfect equilibrium in the specific-trade-tax-choice in the second stage identifying the domestic and foreign welfare functions:

$$
\begin{aligned}
& W_{1}(\cdot)=\int_{0}^{Q} P(Q) d Q-P(Q) Q+\pi_{1}(\cdot)+t_{1} x_{2} \\
& W_{1}(\cdot)=\int_{0}^{Q} P(Q) d Q-P(Q) Q+\pi_{1}(\cdot)+t_{1} x_{2}
\end{aligned}
$$

Proposition 3: The global Nash equilibrium for the optimal specific trade taxes where both countries are reciprocally dumping each other, is described by positive trade taxes in both countries.

Proof: First order conditions from equations (56) and (57), i.e., $\frac{\mathrm{dW}\left(t_{1}\right)}{\mathrm{dt}_{1}}=0=\frac{\mathrm{dW}\left(t_{2}\right)}{\mathrm{dt}_{2}}$, yield: $t_{1}^{o p t}=\frac{1-\tau-c_{x}}{3}$, for the domestic market and $t_{2}^{o p t}=\frac{1-\tau-c_{y}}{3}$, for the foreign market; where: $\tau+c_{x}<1$, and $\tau+c_{y}<1$, to have non-negative trade taxes.

The last two conditions define the home and foreign optimal policies as in the home country case alone. However, it is worth noting that home and foreign governments are only concerned about local production and that they can only influence the choice made by its representative firms through its managed trade policy, not their counterparts.

In this context, there is an additional element that deserves our attention. If there were a managed-trade-protection game between home and foreign governments, although the production choice does accrue to each firm, it is true that it also depends on the çredible commitment"both governments have to grant managed trade protection.

Therefore, even though firms' production decisions do not depend on the action of its rival's government, we could have a subgame perfect equilibrium where governments credible commit or not to grant managed trade protection. In that case, the subgame has the structure of a Prisoner's Dilemma.

To formalize this, let us obtain the home and foreign welfare expressions in the context of this subgame perfect equilibrium. The following table concentrate the results when I further assume without losing of generalization that $c_{y}=$ $c=c_{x}$ and zero transport $\operatorname{costs} \tau=0$ are taking place:

$$
\begin{array}{ccc} 
& t_{1}=0 & t_{1}=\frac{1-\tau-c}{3} \\
t_{1}=0 & \frac{2}{9}(1-c)^{2} ; \frac{2}{9}(1-c)^{2} & \frac{25}{81}(1-c)^{2} ; \frac{2}{9}(1-c)^{2} \\
t_{2}=\frac{1-\tau-c}{3} & \frac{2}{9}(1-c)^{2} ; \frac{25}{81}(1-c)^{2} & \frac{25}{81}(1-c)^{2} ; \frac{25}{81}(1-c)^{2}
\end{array}
$$

These results clearly show that the unique equilibrium is where both firms are protected, this case generates the higher gross domestic private benefits ${ }^{22}$.

\footnotetext{
${ }^{22}$ By assuming zero transport costs, i.e., $\tau=0$, we do not loose generality as long as otherwise, $\tau \in\left(0, \frac{1}{4}\right)$.
} 
Proposition 4: Any trade liberalization from the optimal upper bound tariff: $t=\frac{1-\tau-c}{3}$, can never increase domestic and/or foreign welfare.

Once the optimal trade tax is obtained, if that level were an upper bound from where liberalization started, it will not generate sufficient private incentives for the domestic and the foreign firms to dump in its counterpart's market, so that the domestic and foreign firms would have a production choice as if they were in a situation of autarky. At this point, it should be clear that in this model, autarky is never an optimal choice.

\subsection{Domestic welfare}

To explore how private and social incentives to dump interact each other, I will compare the change in the domestic social welfare that is obtained from the practice of dumping in the context of this model i.e., $\Delta W_{1}$ to the private incentive net of the investment cost, i.e., $B_{1}-F_{1}$. The abovementioned change can be examined in the following equation:

$$
\Delta W_{1}=\Delta C S_{1}+\Delta P S_{1}+\Delta T R_{1}
$$

The first term in eq. (58) represents the change in the consumer surplus, i.e., $\Delta C S$, which is unambiguously positive even though trade protection rises the domestic price to a level higher than that observed under the potential practice of dumping without the managed trade regime. The second term -the change in the producer surplus net of the investment cost $F_{1^{-}}$, is clearly negative as long as the equilibrium price under the managed trade regime is lower than the price obtained under autarky conditions ${ }^{23}$. The third term reflects the change in trade revenues, i.e., $\Delta T R$, and is clearly positive when changing from autarky to trade under this specific trade regime, as long as the trade tax be non-prohibitive. At this point, the main analysis is performed to examine:

$$
\Delta W_{1}-\left(B_{1}-F_{1}\right)=\Delta C S_{1}+\Delta T R_{1}
$$

Where the change in the consumer surplus is the following:

$$
\Delta C S=C S_{1}\left(t_{1}^{o p t}\right)-C S_{1}\left(t_{1}=0\right)=\frac{\left(5-5 c_{x}-2 \tau\right)^{2}}{162}-\frac{\left(1-c_{x}\right)^{2}}{8}
$$

Which is clearly positive for strictly positive values of the marginal cost and the transport cost $c, \tau \gg 0$, and $c \in(0,1)$ with $\tau \in\left(0, \frac{1}{4}\right)$. As for the change in trade revenues, I obtain the next expression:

$$
\Delta T R_{1}=t_{1} x_{2}=\left(\frac{1-c_{x}-\tau}{3}\right)\left(\frac{1-c_{x}-4 \tau}{9}\right)
$$

Therefore,

$$
\Delta W_{1}-\left(B_{1}-F_{1}\right)=\frac{\left(5-5 c_{x}-2 \tau\right)^{2}}{162}-\frac{\left(1-c_{x}\right)^{2}}{8}+\left(\frac{1-c_{x}-\tau}{3}\right)\left(\frac{1-c_{x}-4 \tau}{9}\right) \geq 0
$$

is clearly positive for all relevant values of $c$ and $\tau$.

Proposition 5: The managed trade regime provides both social and private incentives to dump in the counterpart's market, but from the social perspective, these incentives are not enough when the sunk costs to enter the market are in the range $F_{1} \in\left(B_{1}-F_{1}\right)$.

The social benefits of dumping in the counterpart's market while being reciprocally dumped in its own market -net of private benefits-, are positive for all relevant values of marginal production and transport costs. Naturally, sunk costs represented by $F_{1}$ can be

\footnotetext{
${ }^{23}$ Worth noting is that the total change in the producer surplus, i.e., dPS, must be analyzed taking into account the sunk cost $F_{1}$, i.e., $d \pi_{1}-F_{1}$.
} 
potentially high, but if $F_{1}$ falls in the range $\left(B_{1}-F_{1}\right)$, there are no private incentives that compensate social welfare loses to reciprocally dump: adding the sunk cost $F_{1}$ to transport and marginal production costs, i.e., $\tau$ and $c$, would prevent from the practice of reciprocally dumping itself.

\subsection{Global welfare}

This section's main concern is about the effects of the managed trade regime on global welfare. On the one hand, it has been pointed out that there are clear incentives for the domestic and foreign firms to dump each other as long as: i) the perception of the segmented market leads to generate extra revenues from dumping in the counterpart's market, and ii) there is a credible commitment of the government to provide administered protection preventing the price from falling below perfect-competition levels once the practice of dumping has taken place. However, for sufficiently high levels of $F_{1}$ and $F_{2}$, although privately desirable, the practice of dumping might not take place and therefore, trade taxes' influence on firm's behavior would be null.

To obtain the expression of the world welfare we will add up the expressions for the domestic and foreign welfare in equations (56) and (57) in the following way:

$$
\begin{gathered}
W^{W}=W_{1}+W_{2}= \\
\int_{0}^{Q} P(Q) d Q-P(Q) Q+\pi_{1}(\cdot)+t_{1} x_{2}+\int_{0}^{Z} P(Z) d Z-P(Z) Z+\pi_{2}(\cdot)+t_{2} y_{1}
\end{gathered}
$$

Then substituting $t_{1}^{o p t}=\frac{1-\tau-c_{x}}{3}$ and $t_{2}^{o p t}=\frac{1-\tau-c_{y}}{3}$, allowing the practice of dumping to exist, and comparing with a situation where the practice of dumping does not take place, i.e., $t_{1}=0=t_{2}$, this expression becomes:

$$
W^{W}=W_{1}\left(t_{1}^{o p t}, t_{2}^{o p t}\right)-W_{1}\left(t_{1}=0, t_{2}=0\right)+{ }_{2}\left(t_{1}^{o p t}, t_{2}^{o p t}\right)-W_{2}\left(t_{1}=0, t_{2}=0\right)
$$

Finally,

$\Delta W^{W}=\frac{(5-5 c-2 \tau)^{2}}{81}+\frac{2(2 \tau-4 c+4)^{2}}{81}+\frac{2(1-4 \tau-c)^{2}}{81}+\frac{2(1-c-\tau)(1-c-4 \tau)}{27}-\frac{3(1-c)^{2}}{4} \geq 0$

This expression is positive for all relevant values of $\tau$ and c, i.e., c, $\tau \gg 0$, where $c \in(0,1)$ while $\tau \in\left(0, \frac{1}{4}\right)$.

Proposition 6: Global welfare is higher under reciprocal dumping in a managed trade regime. Any bilateral trade liberalization can never increase global welfare.

Like in the domestic welfare analysis, any trade liberalization from the optimal trade tax, being even and unbound tariff, will only deprive domestic and foreign firms with sufficient incentives to start trading each other.

\section{Conclusions}

Far beyond the theoretical treatment to the antidumping code and the application of antidumping duties, it is clear that it has been used as a relief to the import competing industries in both advanced and emerging economies. The lack of analytical formal guidelines to determine the margin of dumping, the material injury and their causality in the antidumping agreement, have led to unreliable findings to the antidumping authorities.

Nevertheless, as in the case of the antitrust system, the possibility to make the type Ierror punishing the competitive behavior is very high. Fortunately, the multilateral system through the Dispute Settlement Body gives the opportunity to settle trade disputes that arise due to the application of the antidumping agreement. Although the aim of this body is to prevent trade retaliations between members, the ultimate word belongs to the countries which may misunderstood the application of the agreements. 
It is important to mention that the market distortions caused by the practice of dumping in the domestic economy are very important as to counteract its effects, but the antidumping agreement should only be applied as a second-best policy due to the imperfections and the asymmetries in the international markets' structure.

The limited commitment the domestic and foreign countries have to sustain a managed trade regime in a context of segmented markets, provide the necessary private economic incentives to build a case of international trade where the monopoly distortion is reduced with the practice of dumping. In this context, it is highly recommendable to include retaliatory costs while the practice of dumping is still seen as illegal and predatory all over the world.

The optimal trade tax provides protection to the segmented markets reducing the efficiency achieved at dumping prices. Even though the price that consumers face is higher under the managed trade regime, this price is still lower than the price realized under autarky conditions. However, there are welfare costs associated with the volume of imports of the homogeneous product: as long as the market participation of imports be positive, transport costs reduce welfare in both countries. The balance between the sources of welfare gains and losses, depend on the specific form the market demand takes place and the level of the transport cost.

\section{Referencias}

Blonigen, B. and Prusa, T. (2015). Dumping and Antidumping Duties. National Bureau of Economic Research, NBER Working Paper No. w21573.

Boltuck, R. (1987). An economic analysis of dumping. Journal of World Trade Law, 21(5), pp.43-54.

Brander, J. and Krugman, P. (1983). A 'reciprocal dumping' model of international trade. Journal of International Economics, 15(3-4), pp.313-321.

Brander, J. and Spencer, B. (1985). Export subsidies and international market share rivalry. Journal of International Economics, 18(1-2), pp.83-100.

Dixit, A. (1988). Anti-dumping and countervailing duties under oligopoly. European Economic Review, 32(1), pp.55-68.

Eaton, J. and Grossman, G. (1986). Optimal Trade and Industrial Policy under Oligopoly. The Quarterly Journal of Economics, 101(2), p.383.

Feinberg, R. and Reynolds, K. (2018). How do countries respond to anti-dumping filings? Dispute settlement and retaliatory anti-dumping. World Economy, 41(5), p.p.1251-1268.

Finger, J. (1992). Dumping and Antidumping: the rhetoric and the reality of protection in industrial countries. The World Bank Research Observer, 7(2), pp.121-144.

Friberg, R. and Ganslandt, M. (2008). Reciprocal Dumping with Product Differentiation. Review of International Economics, 16(5), pp.942-954.

Gallegos, A. (2017). Managed Trade and Environmental Policy under Imperfect Competition. Revista Mexicana de Economía y Finanzas, 12(3), pp.29-44.

Lahiri, S. and Sheen, J. (1990). On Optimal Dumping. The Economic Journal, 100(400), p.127.

Miranda, J., Raúl A. Torres, R. and Ruiz, M. (1998). The International use of Antidumping: 1987-1997. Journal of World Trade, 32(5), pp. 5-71.

Nelson, D. (2006). The political economy of antidumping: A survey. European Journal of Political Economy, 22(3), pp.554-590.

Oshiro, J. (2013). Tariff policy and transport costs under reciprocal dumping. Papers in Regional Science, 92(3), pp.599-608.

Regibeau, P. and Gallegos, A. (2004). Managed Trade, Trade Liberalization and Local Pollution. Advances in Economic Analysis Policy, 3(2).

Spencer, B. and Brander, J. (1983). International R D Rivalry and Industrial Strategy. The Review of Economic Studies, 50(4), p.707. 